\title{
The flavonoid nobiletin inhibits tumor growth and angiogenesis of ovarian cancers via the Akt pathway
}

\author{
JIANCHU CHEN ${ }^{1,2}$, ALLEN Y. CHEN ${ }^{3}$, HAIZHI HUANG ${ }^{1,2}$, XINGQIAN YE $^{1}$, \\ WILLIAM D. ROLLYSON ${ }^{4}$, HALEY E. PERRY ${ }^{4}$, KATHLEEN C. BROWN ${ }^{4}$, \\ YON ROJANASAKUL ${ }^{3}$, GARY O. RANKIN ${ }^{4}$, PIYALI DASGUPTA ${ }^{4}$ and YI CHARLIE CHEN ${ }^{2}$
}

\author{
${ }^{1}$ College of Biosystems Engineering and Food Science, Fuli Institute of Food Science, Zhejiang University, P.R. China; \\ ${ }^{2}$ College of Science, Technology and Mathematics, Alderson Broaddus University, Philippi, WV 26416; \\ ${ }^{3}$ Department of Pharmaceutical Science, West Virginia University, Morgantown, WV 26506; ${ }^{4}$ Department of Pharmacology, \\ Physiology and Toxicology, Joan C. Edwards School of Medicine, Marshall University, Huntington, WV 25755, USA
}

Received February 10, 2015; Accepted March 19, 2015

DOI: $10.3892 /$ ijo.2015.2946

\begin{abstract}
Despite its importance, the death rate of ovarian cancer has remained unchanged over the past five decades, demanding an improvement in prevention and treatment of this malignancy. With no known carcinogens, targeted prevention is currently unavailable, and efforts in early detection of this malignancy by screening biomarkers have failed. The inhibition of angiogenesis, also known as angioprevention, is a promising strategy to limit the growth of solid tumors, including ovarian cancers. Nobiletin, a polymethoxy flavonoid compound isolated from the tiansheng plant, has been shown to inhibit the growth of multiple types of human cancers. However, there are no reports involving the effect on nobiletin on human ovarian cancer. The present report shows that nobiletin potently decreases the viability of ovarian cancer cells in vitro. However, nobiletin does not affect the viability of normal ovarian epithelial cells at $<40 \mu \mathrm{M}$. The antitumor activity of nobiletin was also observed in athymic mouse models and in chicken chorioallantoic membrane (CAM) models. The anti-neoplastic activity of nobiletin was due to its ability to inhibit angiogenesis. We also studied the molecular mechanisms by which nobiletin suppresses angiogenesis. We observed that nobiletin inhibits secretion of the key angiogenesis mediators, Akt, HIF-1 $\alpha, \mathrm{NF}-\kappa \mathrm{B}$ and vascular epithelial growth factor (VEGF) by ovarian cancer cells. Transient transfection experiments showed that nobiletin inhibits production of HIF-1 $\alpha$ by downregulation of Akt. Such decreased levels of HIF-1 $\alpha$ were responsible for nobiletin-induced suppression
\end{abstract}

Correspondence to: Dr Yi Charlie Chen, College of Science, Technology and Mathematics, Alderson Broaddus University, Philippi, WV 26416, USA

E-mail: chenyc@ab.edu

Key words: nobiletin, ovarian cancer, angiogenesis, HIF-1 $\alpha$, vascular epithelial growth factor, Akt of VEGF. Our data suggest that nobiletin may be a promising anti-angiogenic agent relevant for therapy of ovarian cancers.

\section{Introduction}

Ovarian cancer is one of the most serious malignancies for women in the world, ranking as the fifth leading cause of cancer-related deaths (1) and the death rate of ovarian cancer has not seen any remarkable changes for over five decades in the USA (2). Due to a lack of effective biomarkers for screening $(3,4)$, nearly $60-70 \%$ of ovarian cancers are diagnosed at advanced stages (5), with a poor prognosis of $\sim 30 \%$ for a 5-year survival rate (6). These facts emphasize the need for novel therapies to prevent and treat ovarian cancer. Several lines of evidence indicate that nutritional compounds display potent anticancer activity in many human cancers (5). The identification of nutritional agents that can suppress the growth and progression of ovarian cancer could lead to new treatment modalities and improved patient outcomes for this lethal malignancy.

Recent studies have focused on the anticancer activity of flavonoids isolated from plants and animals. Flavonoids are natural polyphenols present in a wide variety of fruits and vegetables (7). Some flavonoids, such as apigenin, genistein and catechin, have been shown to inhibit the growth of ovarian, breast, colon, prostate and leukemia cancer cells (8-17). Nobiletin $(5,6,7,8,30,40$-hexamethoxyflavone) is a polymethoxyflavonoid found in citrus fruits such as Citrus depressa and Citrus reticulate (18). Previous mammalian in vivo studies show that nobiletin can suppress inflammation-associated tumorigenesis aberrant cell proliferation and colon carcinogenesis (19-21). Nobiletin has been also shown to suppress angiogenesis in vitro in human umbilical vein endothelial cells. The anti-angiogenic activity of nobiletin has been shown in chicken chorioallantoic membranes and in zebrafish models $(22,23)$. It has been revealed that nobiletin exhibited a cell differentiation-modulating activity $(24,25)$ and inhibited the phosphorylation of $\operatorname{MEK}(26,27)$. Nobiletin is a decreases metastasis of human fibrosarcoma HT-1080 cells and gastric cancers (27). The mitogen-activated protein 
kinase (MAPK) signaling pathway is a key regulator of cell proliferation, survival and differentiation. The MAPK pathway is constitutively activated in ovarian cancers via gain of function mutations in Ras or Raf. In addition, mutations in PI-3 kinase pathway have been implicated in the progression of ovarian cancers. The hyperactivation of the MAP kinase pathway facilitates the neoplastic transformation of ovarian tumors. Selective MEK1 inhibitors have been shown to suppress the growth of estrogen-responsive ovarian cancers. Since nobiletin also functions as a MEK1 inhibitor we conjectured that perhaps it could suppress the growth of human ovarian cancers. The growth-inhibitory activity of nobiletin has yet to be studied in ovarian cancer. Our report fills this void of knowledge and describes the anti-neoplastic activity of nobiletin in human ovarian cancer. In this report, we show that nobiletin decreases the viability of the human ovarian cancer cell lines OVCAR-3 and CP-70. The growth-inhibitory effects of nobiletin were observed at concentration as low as $5 \mu \mathrm{M}$. Nobiletin had no effect on the viability of normal ovarian epithelial cells at $<40 \mu \mathrm{M}$. Therefore, it displayed a strong selectivity for human ovarian cancer cells over normal ovarian cells. Nobiletin potently decreased the growth rate of human ovarian tumors xenografted in athymic mouse models and chicken CAM models. The anticancer activity of nobiletin was correlated with its anti-angiogenic and anti-apoptosis activity in ovarian cancers. We also analyzed the signaling pathways underlying the anti-angiogenic activity of nobiletin. The antiangiogenic activity of nobiletin was correlated with decreased levels of Akt, HIF-1 $\alpha, \mathrm{NF}-\kappa \mathrm{B}$ and vascular epithelial growth factor (VEGF) in ovarian cancer cells. Taken together, our data suggest that nobiletin may have applications in the therapy of human ovarian cancer.

\section{Materials and methods}

Ethics statement. Male four-week-old athymic mice were obtained from Charles River Laboratories and acclimatized for one week. They were housed in autoclaved cages with ad libitum access to food and water in HEPA-filtered racks and closely monitored by animal facility staff. All procedures involving nude mice were conducted according to the Animal Care and Use guidelines in a facility accredited by the Association for Assessment and Accreditation of Laboratory Animal Care (AAALAC) International and were approved by the Institutional Animal Care and Use Committee (IACUC) of Joan C. Edwards School of Medicine, Marshall University (protocol no. 560).

Reagents, antibodies and constructs. Nobiletin was prepared from a polymethoxyflavonoid mixture, which was provided by Zhejiang Quzhou Tiansheng Plant Extraction Co. Ltd. in China, containing $\sim 60 \%$ nobiletin and tangeretin. The polymethoxyflavonoid mixture was dissolved in methanoldimethyl sulfoxide (1:1), its concentration was $50 \mathrm{mg} / \mathrm{ml}$, then chromatographed with high-performance liquid chromatography (HPLC) (Waters) eluted with methanol- $\mathrm{H}_{2} \mathrm{O}$ (70:30) in $8 \mathrm{ml} / \mathrm{min}$ at room temperature, separated into two fractions, collected individually, evaporated, obtained fraction I and fraction II. Fraction I was identified as nobiletin (Fig. 1A) by HPLC-MS, UV-vis chromatography and comparing peak time with that of nobiletin sample from Sigma and previous reports (data not shown). Its purity was $>98 \%$. Monoclonal antibodies against HIF-1 $\alpha, \mathrm{NF}-\kappa \mathrm{B}$ (p50), PTEN, c-Myc, GAPDH, p-AKT, total AKT, p-mTOR and total mTOR were purchased from Santa Cruz Biotechnology (Santa Cruz, CA, USA). The secondary antibodies of anti-rabbit and anti-mouse were purchased from Thermo Scientific (Pierce, Rockford, IL, USA). The HIF- $1 \alpha$ and mAkt plasmid constructs were obtained from Addgene (www.addgene.org) (28).

Cell culture and treatment. Human ovarian cancer cell lines, OVCAR-3 and A2780/CP70, were provided by Dr B. Jiang, Department of Microbiology, Immunology, and Cell Biology, West Virginia University. IOSE-364, normal ovarian surface epithelial cells from healthy women, but immortalized with SV40 T/t, were courtesy of Dr N. Auersperg at University of British Columbia, Canada. All cells were maintained in RPMI-1640 medium supplemented with $100 \mathrm{U} / \mathrm{ml}$ penicillin, $100 \mu \mathrm{g} / \mathrm{ml}$ streptomycin and 10\% US-qualified fetal bovine serum (Invitrogen, Grand Island, NY, USA) in a humidified incubator with $5 \% \mathrm{CO}_{2}$ at $37^{\circ} \mathrm{C}$. Nobiletin was dissolved in dimethyl sulfoxide (DMSO) to make stock solutions of $100 \mathrm{mM}$ and equal amount of DMSO was included in controls for every experiment.

Cell proliferation. The effect of nobiletin on the viability of ovarian cancer cells (OVCAR-3 and A2780/CP70) colorimetrically determined with a CellTiter 96 Aqueous One Solution Cell Proliferation Assay kit from Promega (Madison, WI, USA). The cells were seeded into 96 -well plates at a density of $5 \times 10^{3} /$ well and incubated for $24 \mathrm{~h}$ at $37^{\circ} \mathrm{C}$. Subsequently, the cells were treated with vehicle or varying concentrations of nobiletin for another $24 \mathrm{~h}$ at $37^{\circ} \mathrm{C}$. After $24 \mathrm{~h}$, the medium was removed and cell viability was measured according to the manufacturer's instructions. Each sample was measured in triplicate. Cell viability was expressed as percentage of control from three independent experiments.

Apoptosis assay. The apoptotic effects of nobiletin on ovarian cancer cells were determined by FITC Annexin V Apoptosis Detection Kit I from BD Biosciences. Cells were washed with cold PBS twice and then were resuspended in binding buffer at a concentration of $1 \times 10^{6} / \mathrm{ml}$. An aliquot of $100 \mu \mathrm{l}$ of the cell solution $\left(1 \times 10^{5}\right.$ cells) was transferred to a $5-\mathrm{ml}$ tissue culture tube. Subsequently, $5 \mu \mathrm{l}$ of FITC Annexin V and $5 \mu 1$ propidium iodide (PI) was added to the cells. The cells were gently vortexed and incubated for $15 \mathrm{~min}$ at room temperature in the dark. The next step involved the addition of $400 \mu \mathrm{l}$ of $1 \mathrm{X}$ binding buffer to each tube. The samples were analyzed by flow cytometry (Cytomic FC 500MCL) within $1 \mathrm{~h}$. Three independent experiments were assayed. Data represent mean \pm SE from 3 independent experiments.

ELISA for VEGF. The levels of VEGF in cell culture supernatants were analyzed by a Quantikine Human VEGF Immunoassay kit (R\&D Systems, Minneapolis, MN, USA). Cells $\left(1 \times 10^{4} /\right.$ well) were seeded into 96 -well plates and incubated overnight. Subsequently, the cells were treated with nobiletin for $16 \mathrm{~h}$ in serum-free medium. Culture supernatants were collected and spun down at $10,000 \mathrm{~g}$ at $4^{\circ} \mathrm{C}$. The superna- 


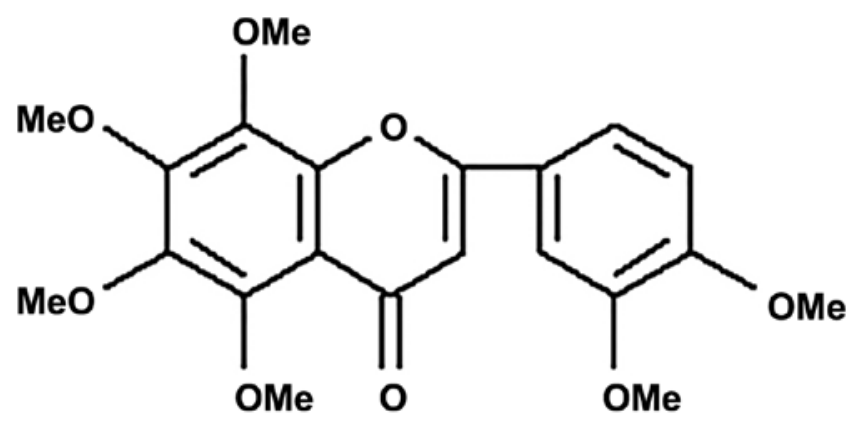

Figure 1. Structure of nobiletin.

tant was collected and stored at $-70^{\circ} \mathrm{C}$. The amounts of VEGF were measured following the manufacturer's instructions, and normalized to cell numbers for each treatment. A total of three independent experiments, each in triplicates, were assayed, and the mean VEGF protein level from each triplicate was used for statistical analysis.

Western blot analysis. Ovarian cancer cells $\left(10^{6}\right)$ were seeded in 60-mm dishes and incubated for $16 \mathrm{~h}$ before treated with nobiletin for $24 \mathrm{~h}$. The cells were washed with PBS, lysed in $100 \mu \mathrm{l}$ mammalian protein extraction reagent including 11 halt protease, $1 \mu \mathrm{l}$ phosphatase inhibitor and $2 \mu \mathrm{l}$ EDTA (M-PER, Pierce), according to the manufacturer's instructions. Total protein levels were assayed with a BCA Protein Assay kit (Pierce). Forty microgram of protein lysates was separated by $10 \%$ SDS-PAGE and transferred into nitrocellulose membrane with a Mini-Protean 3 system (Bio-Rad Laboratories, Hercules, CA, USA). The membranes were blocked in 5\% milk in PBS containing $0.1 \%$ Tween-20 for $1 \mathrm{~h}$ at room temperature. The membranes were incubated with the appropriate dilutions of the primary antibodies and secondary antibodies. The signal obtained in the western blot experiments was detected by the SuperSignal West Dura Extended Duration Substrate (Pierce Biotechnologies). Protein bands were quantitated with NIH ImageJ software, normalized by corresponding GAPDH or total AKT, total mTOR bands, and expressed as percentages of control. A total of three independent experiments were carried out for statistical analysis.

Transient transfection and reporter assay. Transient transfection and reporter assay were modified from our published report $(28,29)$. Ovarian cancer cells were seeded in 96-well plate at 10,000 cells/well and incubated overnight. For transfection with HIF- $1 \alpha / \mathrm{mAkt}$ plasmids, cells were then transfected with $0.05 \mu \mathrm{g}$ VEGF luciferase reporter, 0-0.25 $\mu \mathrm{g}$ HIF- $1 \alpha / \mathrm{mAkt}$ or SR- $\alpha$ (as vehicle) plasmids by $0.6 \mu 1$ jetPRIME reagent (VWR) for $4 \mathrm{~h}$ and removed the medium. Followed by $16-\mathrm{h}$ treatment with $0-$ or $40-\mu \mathrm{M}$ nobiletin. The cells were harvested and analyzed for luciferase activities with ONE-Glo Luciferase Assay system (Promega) and detected by Lumat LB9507 (Berthold Technologies). Total protein levels with a BCA Protein Assay kit (Pierce), and the activities of VEGF reporter were normalized by corresponding total protein levels for statistical analysis. The experiments were conducted three times.
Chicken embryo chorioallantoic membrane (CAM) assay. The A2780 cells at grown to $70 \%$ confluence, were harvested, washed with PBS and re-suspended in serum-free medium. Aliquots of the cells $\left(0.1 \mathrm{ml}, 2 \times 10^{7} / \mathrm{ml}\right)$ were mixed with $0.1 \mathrm{ml}$ of Matrigel (BD Bioscience, San Jose, CA, USA), supplemented with 0 or $20 \mu \mathrm{M}$ nobiletin, pre-gelled on an autoclaved silicone mat for 30-40 min, and implanted onto the CAM of 9-day-old chicken embryo. Chicken embryos were incubated for 4-5 days, photographed for Matrigel implant, and counted for branching blood vessels. Angiogenesis was evaluated by normalizing number of branching vessels to that of control CAM. A total of 10 eggs were assayed for each group.

Antitumor studies in athymic mice. Twenty-four week-old male nude mice were obtained from Charles River Laboratories and acclimatized for one week. They were housed in autoclaved cages with ad libitum access to food and water in HEPAfiltered racks and closely monitored by animal facility staff. All procedures were conducted according to the Animal Care and Use guidelines in a facility accredited by the Association for Assessment and Accreditation of Laboratory Animal Care (AAALAC) International and were approved by the Institutional Animal Care and Use Committee (IACUC) of Joan C. Edwards School of Medicine, Marshall University (protocol no. 560).

CP70 cells were harvested and re-suspended in a 1:1 (v/v) solution of serum-free media and Matrigel matrix (BD Biosciences). Two million cells in $100 \mu 1$ were injected subcutaneously between the scapulae of each mouse (30). After the tumors reached $100 \mathrm{~mm}^{3}$, the mice were randomized and divided into two groups comprising of ten mice each. The treatment group $(\mathrm{N}=10)$ was fed AIN-76A diet with 5\% lipid level containing $100 \mathrm{mg}$ nobiletin/ $\mathrm{kg}$ food. The control group $(\mathrm{N}=10)$ was fed AIN76A diet containing vehicle. Mice were weighed once per week. Their food consumption was monitored daily. Tumor volumes were calculated as $\left(1 \mathrm{x} \mathrm{w}^{2}\right) / 2$ $(31,32)$.

Statistical analysis. Results are expressed as mean \pm standard error of mean (SEM) using Microsoft Excel (Windows 8). Statistical assessment was carried out with the program system of SPSS (Version 16.0 for Windows). The results were analyzed using one-way analysis of variance (ANOVA) and post hoc test (2-sided Dunnett's test) to test both overall differences and specific differences between each treatment and control. A P-value of $<0.05$ was considered statistically significant.

\section{Results}

Effect of nobiletin on ovarian cancer cell viability. The treatment of OVCAR-3 and CP70 ovarian cancer cells with nobiletin caused a concentration-dependent decrease in cell viability over $24 \mathrm{~h}$. Beginning at a concentration of $5 \mu \mathrm{M}$ nobiletin, OVCAR-3 cell viability consistently decreased from $95 \pm 1$ to $28 \pm 4 \%$ at a concentration of $160 \mu \mathrm{M}$ nobiletin $(\mathrm{P}<0.01)$ (Fig. 2A). Similarly, CP70 cell viability was also suppressed with different concentration. At a concentration of $5 \mu \mathrm{M}$ nobiletin cell viability was $96 \pm 1 \%(\mathrm{P}<0.05)$, that was gradually inhibited to $26 \pm 3 \%$ by a $160-\mu \mathrm{M}$ nobiletin treatment 
A

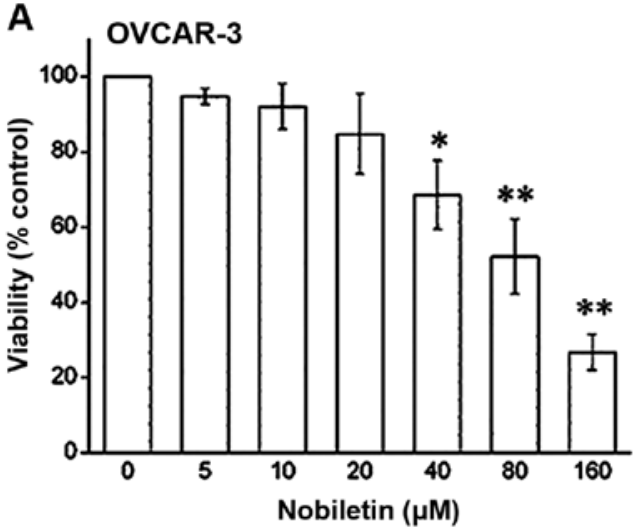

C

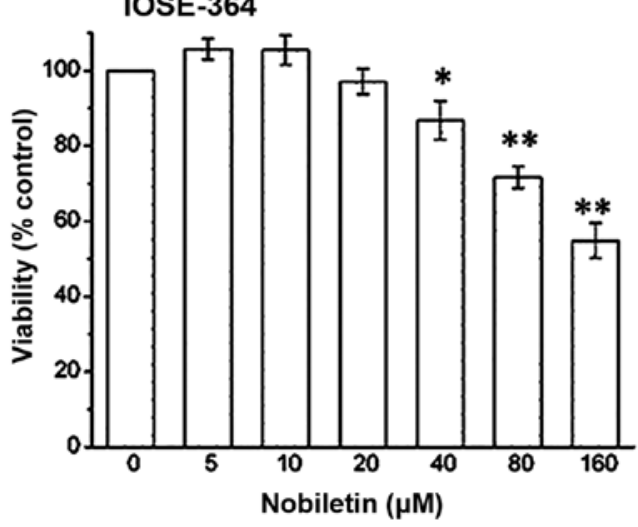

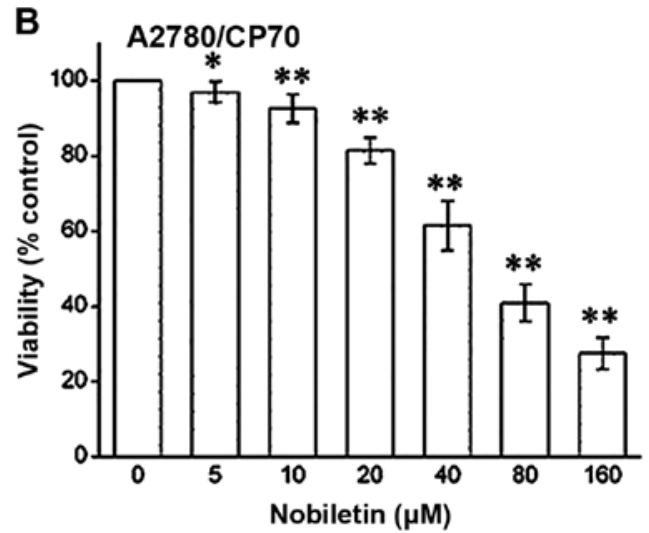

D

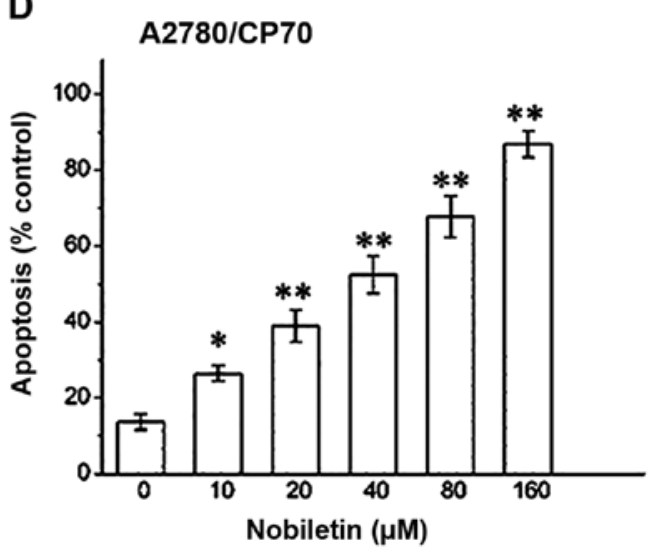

Figure 2. Nobeletin decreased the viability and induced apoptosis of human ovarian cancer cells in a concentration-dependent manner. (A) Cell viability assays showed that the treatment of OVCAR-3 cells with varying concentrations of nobiletin caused a decrease in cell viability. (B) The cell viability assay was repeated in A2780/CP70 cells. (C) Cell viability results were obtained in IOSE-364 cells. (D) Apoptosis assay showed that nobiletin induced apoptosis of A2780/CP70 ovarian cancer cells. Data represent mean \pm SE from 3 independent experiment. ${ }^{*} \mathrm{P}<0.05$ as compared to control. ${ }^{* *} \mathrm{P}<0.01$ as compared to control.

$(\mathrm{P}<0.01)$ (Fig. 2B). We also examined the growth inhibitory activity of nobiletin on IOSE-364 normal ovarian cells (Fig. 2C). We observed that nobiletin had a lower growthinhibitory activity in IOSE-364 cells than in A2780 ovarian cancer cells. Therefore, our data suggest that nobiletin is somewhat more selective towards ovarian cancer cells than normal cells.

Effect of nobiletin on ovarian cancer cell apoptosis. We ascertained that the growth inhibitory effects of nobeletin were due to cellular apoptosis. Annexin FITC assays revealed that nobiletin induced apoptosis in CP70 ovarian cancer cells in a concentration-dependent manner (Fig. 2D). CP70 cell apoptosis was $13 \pm 1 \%$ when it was not treated with nobiletin, which was significant increased at a concentration of $10 \mu \mathrm{M}$ nobiletin (26 $\pm 2 \%)$. CP70 cell apoptosis was gradually increased to $88 \pm 2 \%$ by a $160-\mu \mathrm{M}$ nobiletin treatment $(\mathrm{P}<0.01)$.

Effect of nobiletin on angiogenesis and growth of the tumor. To assess whether nobiletin inhibits the growth of human ovarian cancers in vivo, we used the CAM and athymic mouse models to study the effect of nobiletin on the growth rate of human ovarian cancer cells in vivo. The administration of $20 \mu \mathrm{M}$ nobiletin significantly attenuated $(\mathrm{P}<0.01)$ the growth of OVCAR human ovarian tumors implanted on CAM (Fig. 3A and B). We counted the number of blood vessels to assess whether nobiletin was suppressing the growth of ovarian tumors by inhibition of angiogenesis. The chicken CAM experiment was repeated using A2780 cells and similar results were obtained. We observed that the treatment of OVCAR and A2780 cells with $20 \mu \mathrm{M}$ nobiletin was able to inhibit angiogenesis. The implanted cancer cells grow to a tumor weight of $58 \pm 5 \mathrm{mg}$, with $29 \pm 4$ blood vessels counted. Inclusion of $20 \mu \mathrm{M}$ nobiletin in this implant, however, reduced tumor growth down to $34 \pm 3 \mathrm{mg}(\mathrm{P}<0.01)$ and inhibited blood vessel development to $19 \pm 2(\mathrm{P}<0.05)$. We speculated that the effect of nobiletin on the promotion of cancer cell apoptosis and inhibition of angiogesis lead to the growth attenuation of tumors implanted on CAM. A typical image (Fig. 3C) is shown to contrast the tumors with or without nobiletin in terms of both tumor size and angiogenesis. The great effect of nobiletin on inhibiting tumor growth was conformed in vivo using an athymic mouse model, where they exhibited smaller tumor size (Fig. 3D). The tumors implanted on mice grow to a volume of $2450 \mathrm{~mm}^{3}$ at the 15 th day. However, the treatment of nobiletin $(100 \mathrm{mg} / \mathrm{kg}$ food) inhibited tumor growth to $300 \mathrm{~mm}^{3}$.

Effect of nobiletin on VEGF expression. Our results showed that nobiletin significantly inhibited the expression of vascular endothelial grow factor (VEGF) in ovarian cancer cells, 
A

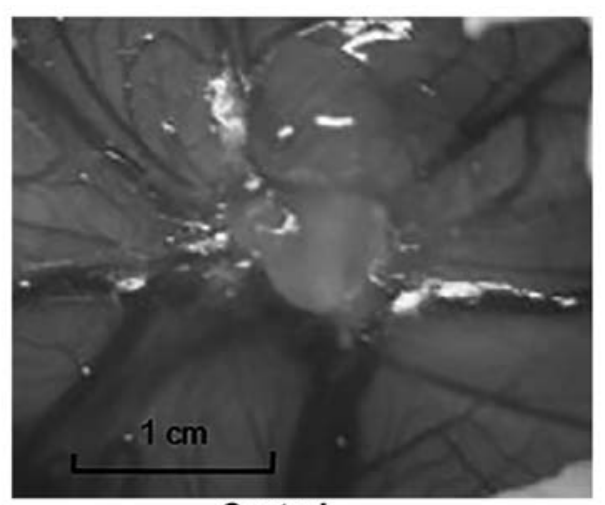

Control

C

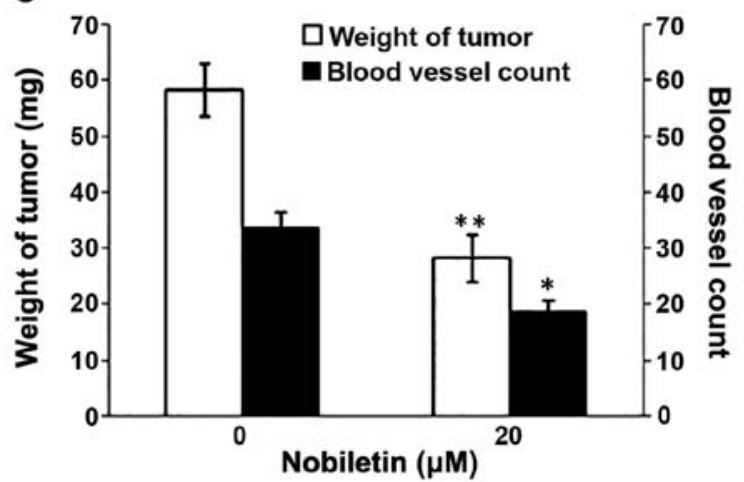

B

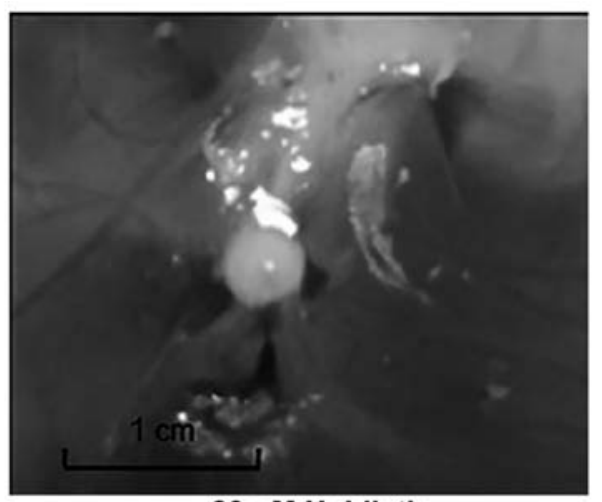

$20 \mu \mathrm{M}$ Nobiletin

D

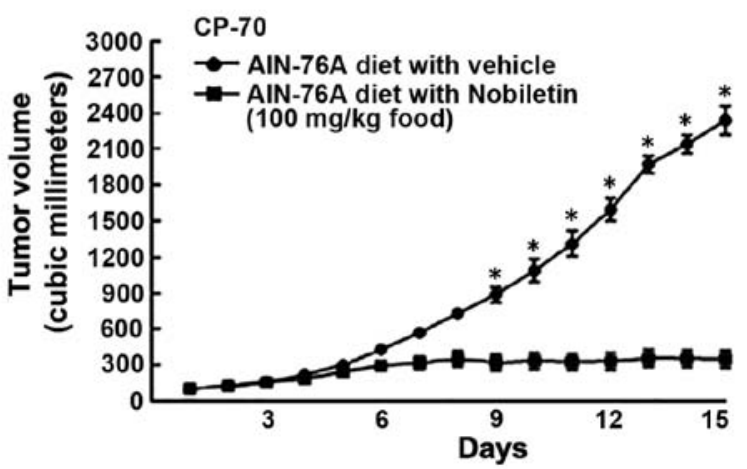

Figure 3. Nobiletin inhibits tumor growth and angiogenesis in CAM and athymic mouse models. Chicken chorioallantoic membrane (CAM) assay showing tumor without nobiletin treatment (A), treated with $20 \mu \mathrm{M}$ nobiletin (B). CAM assays showed that $20 \mu \mathrm{M}$ nobiletin suppressed the growth of blood vessels and A2780/CP70 tumors xenografted on chicken CAM relative to vehicle treated tumors (C). After 5 days of treatment, the tumors were excised, and the blood vessels were counted by phase contrast microscopy. Angiogenesis was evaluated by normalizing number of branching vessels to that of control CAM. The data are presented as mean \pm SEM ( $\mathrm{n}=10$ eggs/group) (C). Nobiletin treatment also significantly inhibited tumor growth in the athymic mice (D).

A

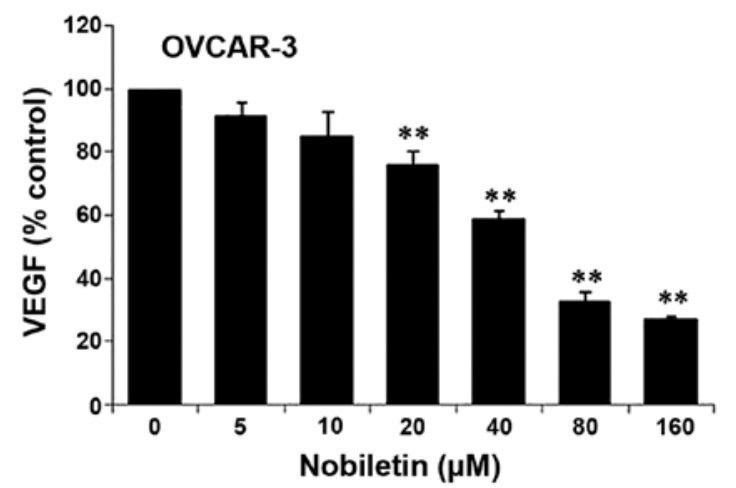

B

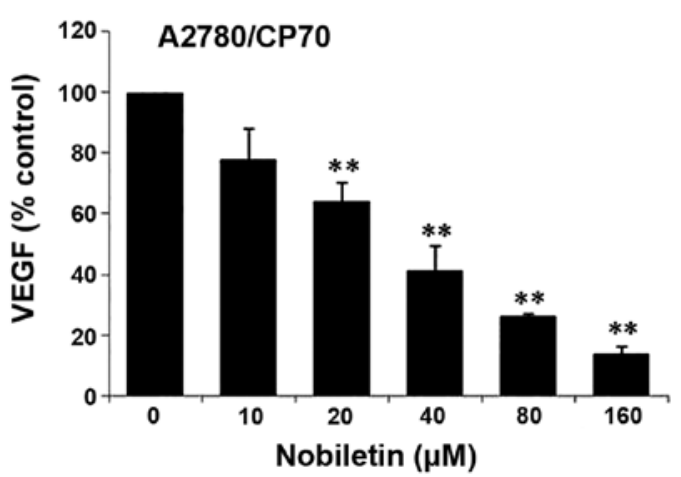

Figure 4. Nobiletin induces a concentration-dependent decrease of VEGF production from human ovarian cancer cells. The human ovarian cancer cell line OVCAR-3 (A), and A2780/CP70 (B) were treated with varying concentrations of nobiletin for $16 \mathrm{~h}$. Subsequently, the VEGF levels in the supernatant was measured by ELISA. A total of three independent experiments, each in triplicates, were assayed, and the mean VEGF protein level from each duplicate was used for statistical analysis. ${ }^{*} \mathrm{P}<0.05$ as compared to control. ${ }^{* *} \mathrm{P}<0.01$ as compared to control.

and this inhibition effect was enhanced with the increase of nobiletin concentration (Fig. 4). In both OVCAR-3 and A2780/ CP-70 cells, the inhibitory effect of nobiletin on VEGF secretion reached a significant level when its concentration was $>20 \mu \mathrm{M}$. The levels of secreted VEGF protein in OVCAR-3 cell culture supernates were downregulated to $77 \pm 2 \%$ at a concentration of $10 \mu \mathrm{M}$ nobiletin $(\mathrm{P}<0.01)$ and to $28 \pm 1 \%$ at a concentration of $160 \mu \mathrm{M}$ nobiletin $(\mathrm{P}<0.01)$ (Fig. 4A). Similarly the levels of secreted VEGF protein in CP70 cells ranged from $66 \pm 2 \%(20 \mu \mathrm{M})$ to $16 \pm 2 \%(160 \mu \mathrm{M})$ with respect to different nobiletin concentration (Fig. 4B).

Signaling pathways underline the growth inhibiting activity of nobiletin. HIF-1 $\alpha$ is one of the key factors for the regula- 
A
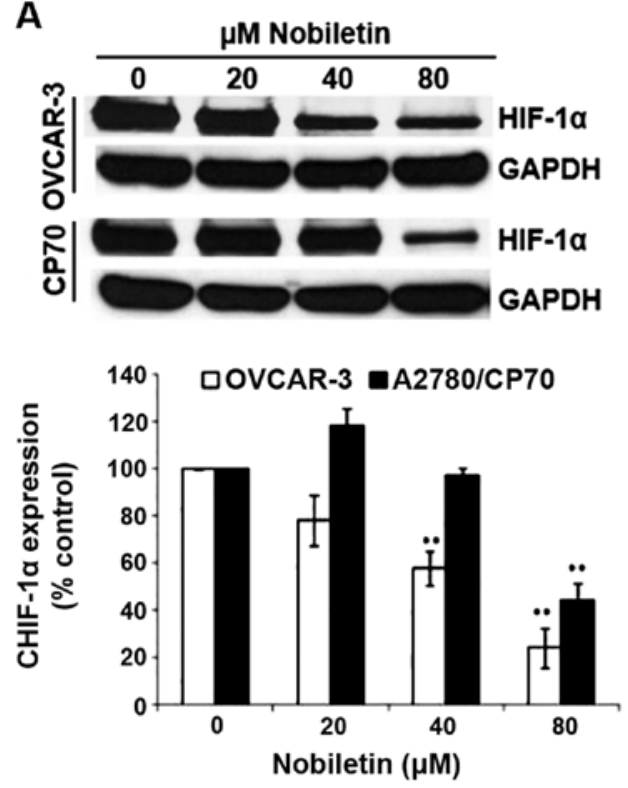

C
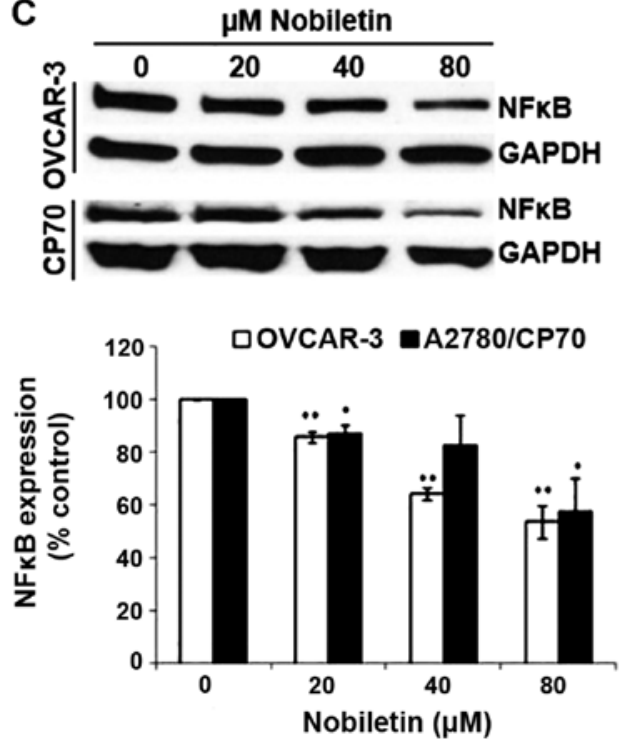

B
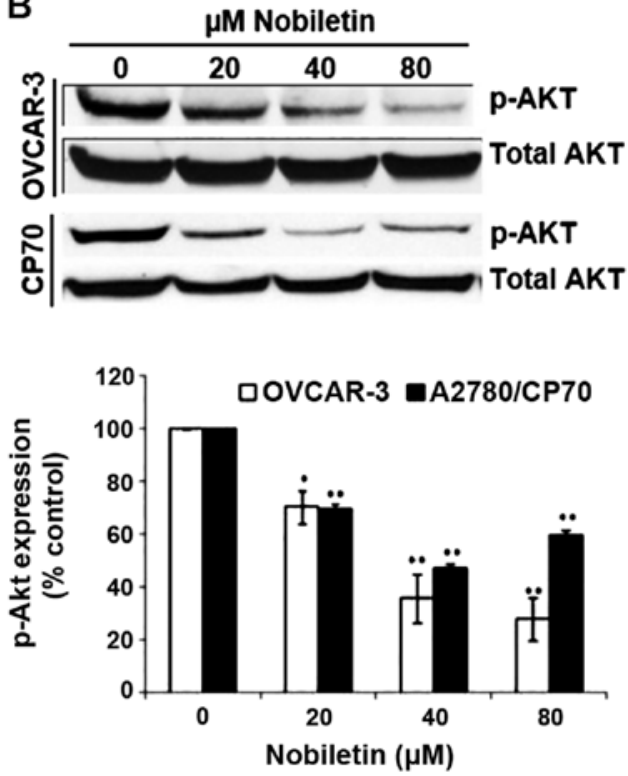

D

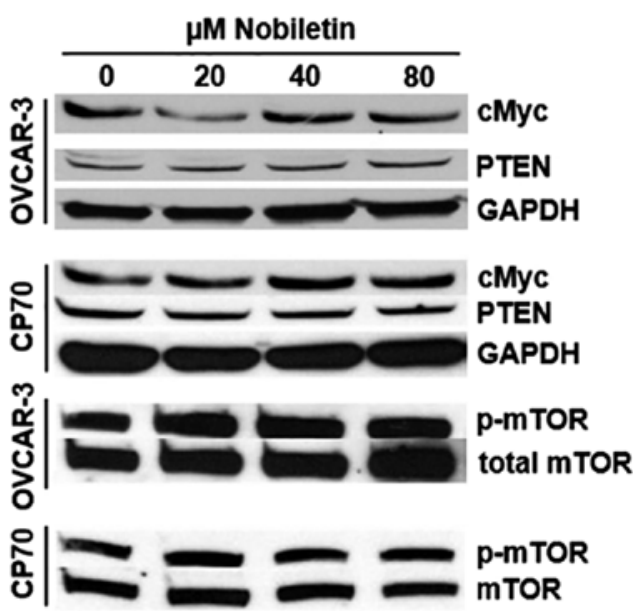

Figure 5. Nobiletin regulates several intracellular signaling pathways in human OVCAR-3 and CP-70 ovarian cells. (A) Nobiletin decreases the levels of HIF-1 $\alpha$ in OVCAR-3 and CP-70 human ovarian cells. Protein bands were quantitated, normalized by corresponding GAPDH bands, and expressed as percentages of control (bar graph below the panel). (B) Nobiletin lowers the phosphorylation of Akt (Ser4) in OVCAR-3 and CP-70 cells. The levels of total Akt are not affected by nobiletin treatment. The bar graph below the panel represents densitometric analysis of the immunoblotting data. (C) Nobiletin decreases NF-KB expression in both ovarian cancer cell lines. (D) Nobiletin had no effect on expression of c-Myc, PTEN, mTOR proteins. Nobiletin had no effect on the phosphorylation of mTOR protein in either ovarian cancer cell line. A total of three independent experiments were carried out for statistical analysis. Data represent mean \pm SE from 3 independent experiment. ${ }^{*} \mathrm{P}<0.05$ as compared to control. ${ }^{* *} \mathrm{P}<0.01$ as compared to control.

tion of VEGF expression. As shown in Fig. 5A, nobiletin had a certain impact on HIF-1 $\alpha$ expression of ovarian cancer cells. For OVCAR-3, 20- $\mu \mathrm{M}$ nobiletin treatment led to inhibition of HIF-1 $\alpha$ protein to $78 \pm 6 \%$ by $24 \mathrm{~h}$ of treatment. Higher concentrations of nobiletin resulted in greater inhibition, with the levels of HIF1- $\alpha$ protein down to $57 \pm 3 \%$ by $40-\mu \mathrm{M}$ nobiletin treatment $(\mathrm{P}<0.01)$ and $23 \pm 3 \%$ by $80-\mu \mathrm{M}$ nobiletin treatment $(\mathrm{P}<0.01)$. However, for CP70, HIF-1 $\alpha$ expression was slightly enhanced $(118 \pm 2 \%)$ when the concentration of nobiletin was $<20 \mu \mathrm{M}$ and was significantly inhibited $(47 \pm 2 \%)$ when its concentration was $80 \mu \mathrm{M}(\mathrm{P}<0.01)$. It seems $\mathrm{CP} 70$ cells were more resistant to the effect of nobiletin than OVCAR-3 cells on HIF-1 $\alpha$ expression.
Nobiletin inhibited phosphorylation of AKT, which is known to be the major signal for cell survival and proliferation (33). As shown in Fig. 5B, nobiletin decreased AKT phosphorylation for both OVCAR-3 and CP70 ovarian cancer cells. P-AKT level was downregulated from $70 \pm 2 \%$ by $20-\mu \mathrm{M}$ nobiletin treatment to $29 \pm 4 \%$ by $80-\mu \mathrm{M}$ nobiletin treatment in OVCAR-3 cells. The phosphorylation of AKT was also inhibited from $69 \pm 1 \%$ by the $20-\mu \mathrm{M}$ nobiletin treatment to $49 \pm 1 \%$ by $40-\mu \mathrm{M}$ nobiletin treatment in CP70 cells. However, the effect of nobiletin on the inhibition of AKT phosphorylation in C70 cells was decreased when treated with $160-\mu \mathrm{M}$ nobiletin. Again, it seems CP70 cells were more resistant to the effect of nobiletin than OVCAR-3 cells on AKT phosphorylation. 
A

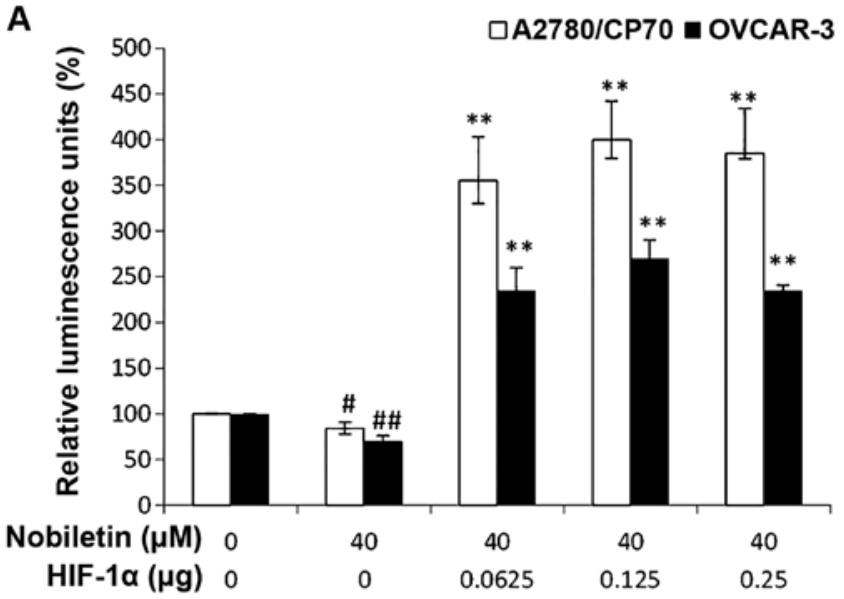

B

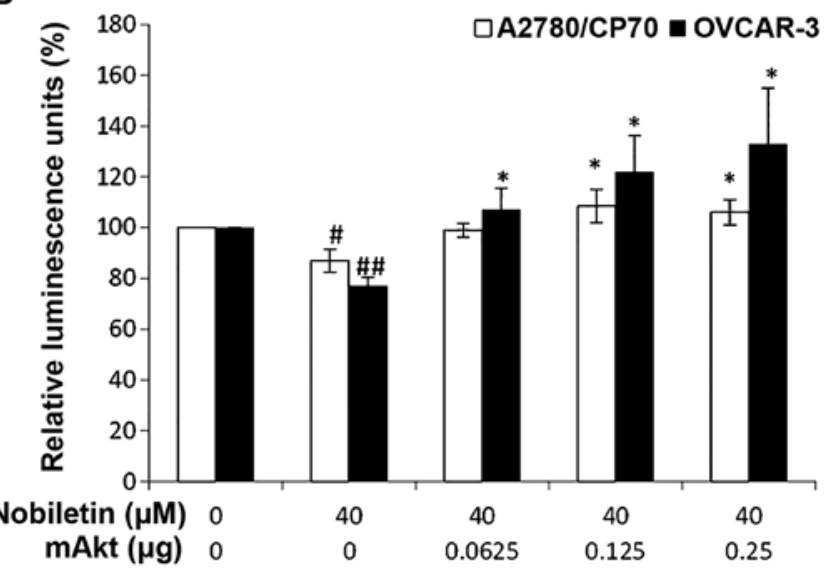

Figure 6. Forcing expression of HIF-1 $\alpha$ protein (A) and Akt protein (B) reversed the effect of nobiletin on VEGF transcriptional activation. OVCAR-3 and A2780/CP70 cancer cells were seeded in a 96-well plate at 10,000 cells/well and incubated overnight. The cells were then transfected with $0.05 \mu \mathrm{g}$ VEGF (HIF-1 $\alpha$ ) luciferase reporter, 0-0.25 $\mu \mathrm{g}$ HIF-1 $\alpha$ (AKT) or SR- $\alpha$ plasmids by $0.6 \mu 1$ jetPRIME reagent for $4 \mathrm{~h}$, followed by 16 -h treatment with 0 or $40 \mu \mathrm{M}$ nobiletin. The cells were harvested and analyzed for luciferase and total protein levels, and the levels of VEGF (HIF-1 $\alpha$ ) reporter were normalized by corresponding total protein levels. Data represent mean \pm SE from 3 independent experiment. ${ }^{*} \mathrm{P}<0.05$ as compared to control. ${ }^{* *} \mathrm{P}<0.01$ as compared to control.

$\mathrm{NF}-\mathrm{kB}$ is a common transcription factor that is related to many signal transduction pathways of cancer cell proliferation and angiogenesis $(34,35)$. The effect of nobiletin on NF- $\mathrm{KB}$ expression is shown in Fig. 5C. Results showed that nobiletin had an impact on NF- $\mathrm{B}$ (p50) expression. The level of NF- $\mathrm{KB}$ (p50) decreased with the increase of nobiletin concentration in OVCAR-3 and CP-70 cells. For OVCAR-3, the inhibitory effect reached a significant level $(87 \pm 1 \%)$ when the concentration of nobiletin was $20 \mu \mathrm{M}(\mathrm{P}<0.01)$. In CP70, NF- $\kappa \mathrm{B}$ (p50) level reduced with the increase of nobiletin concentration, and it reached a significant level when the nobiletin concentration was $20(88 \pm 1 \%)$ and $80 \mu \mathrm{M}(57 \pm 6 \%)(\mathrm{P}<0.05)$.

$\mathrm{c}-\mathrm{Myc}$ is a transcription factor that plays a role in cell cycle progression, apoptosis and cellular transformation. Unlike kaempferol, which inhibited c-Myc protein expression (35), our results indicated that nobiletin did not inhibit c-Myc expression in ovarian cancer cells (Fig. 5D). Its mechanism needs to be further investigated. PTEN acts as a tumor suppressor gene

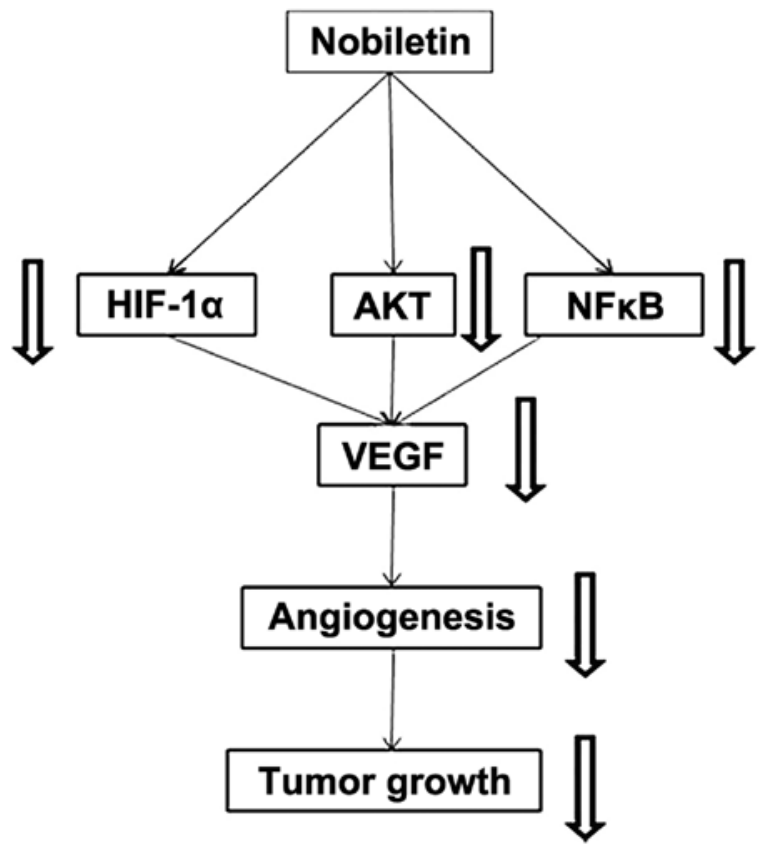

Figure 7. Proposed pathway for the nobiletin effect on tumor growth and angiogenesis.

which is involved in the regulation of the cell cycle, preventing cells from growing and dividing too rapidly (36). The protein of mTOR is a serine/threonine protein kinase that regulates cell growth, cell proliferation, cell motility, cell survival, protein synthesis, and transcription (37). Results also showed that nobiletin had no significant effect on PTEN and p-mTOR expression in ovarian cancer OVCAR-3 and CP-70 (Fig. 5D).

Nobiletin inhibits VEGF by regulating HIF-1 $\alpha$ expression and Akt signaling. To see that HIF-1 is not only regulated by nobiletin treatment, but also plays a role in the nobiletin inhibition on VEGF expression, ovarian cancer cells were transfected with the VEGF-promoter reporter together with HIF-1 plasmids. While nobiletin treatment significantly inhibited VEGF transcriptional activation, this inhibition was concentrationdependent and significantly reversed by forced expression of HIF-1 $\alpha$ protein (Fig. 6A).

The role played by Akt signaling in the nobiletin regulation of VEGF expression was investigated in both ovarian cell lines. It was found that the phosphorylation of Akt was significantly inhibited by 2-h nobiletin treatment (Fig. 6B). After transfecting with VEGF-promoter reporter and mAkt plasmids, VEGF transcriptional activation was significantly reduced by nobiletin treatment in both ovarian cancer cell types, and this effect was significantly reversed by forced expression of Akt protein (Fig. 6B).

\section{Discussion}

Angiogenesis is a necessary condition for sustained tumor growth. Tumor cells take in nutrition and oxygen through the generated blood vessels, which produce substances needed for growth (38). Angiogenesis plays a central role in the development and progression of ovarian cancer (39). Histological studies demonstrated that ovarian tumors are richly vascu- 
larized. A correlation between microvascular count and biological aggressiveness was also found $(40,41)$. Vascular endothelial growth factor (VEGF), as a key regulator of angiogenesis in ovarian cancer, is involved in various steps of ovarian carcinogenesis $(42,43)$. VEGF plays a central role in tumor vasculature development and maintenance. VEGF expression promotes angiogenesis, thereby stimulating tumor growth and metastasis. Hypoxia-inducible factor $1 \alpha(\mathrm{HIF}-1 \alpha)$ is a heterodimeric basic helix-loop-helix protein that directly activates transcription of VEGF gene by binding to a HRE (44). Previous studies showed that nobiletin inhibited angiogenesis in human umbilical vein endothelial cells (HUVECs) and zebrafish models $(22,23,45)$. Similarly, the results showed that nobiletin effectively inhibited angiogenesis in ovarian cancer cells planted on chicken embryos models, indicating its potential to inhibit tumor growth in vivo.

While VEGF expression is an important factor in tumor growth and metastasis, HIF-1 $\alpha$ is one of the key factors for VEGF expression. Previous studies $(46,47)$ showed that the anticancer flavonoid compound kaempferol inhibited angiogenesis in ovarian cancer cells by downregulating HIF-1 $\alpha$ expression. This is consistent with our study, indicating that the nobiletin inhibitory effects on angiogenesis can be traced back to suppression of HIF-1 $\alpha$ expression. However, contradictory results were found in zebrafish models which showed that nobiletin increased mRNA levels of VEGF (22). This could be because nobiletin induced anti-angiogenesis through different mechanism in the two kinds of cells. PI3 kinase/Akt pathways could attenuate ovarian carcinoma through mediating angiogenesis and vascular permeability (48). In addition, taking into consideration previous studies that HIF-1 $\alpha$ is related to the PI3 kinase/Akt signaling pathways (30-32), we tested if nobiletin inhibited expression of VEGF through PI3K/AKT pathways. Our results revealed that nobiletin significantly inhibited the phosphorylation of Akt. The inhibitory effect of nobiletin on Akt phosphorylation was more pronounced than on HIF-1 $\alpha$ expression shown above. Previous studies showed that nobiletin suppressed PI3K/Akt pathways in human HepG2 (49). It was similar to our findings that nobiletin inhibited angiogenesis mainly through Akt pathways which results in the downregulation of VEGF expression (Fig. 6B). The mechanism by which nobiletin inhibits the PI3K/Akt signaling pathway is not fully understood. However, it has been shown that nobiletin suppressed invasion and migration of human gastric adenocarcinoma AGS cells through FAK/ PI3K/Akt pathways (50).

Some researchers found that Akt pathways regulates the expression, activation and translocation of NF- $\kappa \mathrm{B}$ (51-53). Suppression of NF- $\kappa \mathrm{B}$ in tumor samples also inhibits proliferation, causes apoptosis, indicating the crucial role of $N F-\kappa B$ in cell proliferation and survival. We consider that it plays an important role on the nobiletin-induced apoptosis in A2780/ CP70 cells. It was also found that HIF-1 $\alpha$ promoter is responsive to selective $N F-\kappa B$ subunits, indicating that $N F-\kappa B$ is a direct modulator of HIF-1 $\alpha$ expression (54). NF- $\kappa \mathrm{B}$, which is related to many signal transduction pathways of cancer cells (34), has been identified in tumors of epithelial origin such as breast, colon, lung and ovarian cancers (55). Recent research suggested the importance of $N F-\kappa B$ in the propagation of ovarian cancer cell lines (56). It was also found that $\mathrm{NF}-\kappa \mathrm{B}$ had a relationship with angiogenesis; that is, $\mathrm{NF}-\kappa \mathrm{B}$ regulates $\mathrm{c}-\mathrm{Myc}$ expression. Overexpression of $\mathrm{NF}-\kappa \mathrm{B}$ removed the kaempferol inhibitory effect on c-Myc expression (35). Our results showed that the effect of nobiletin on $\mathrm{NF}-\kappa \mathrm{B}$ in ovarian cancer cells varies with cancer cells. Similar to the results found in AKT phosphorylation, NF- $\kappa \mathrm{B}$ levels in the OVCAR-3 cells were more sensitive than those in the CP70 line. Nevertheless, nobiletin treatment significantly reduced $\mathrm{NF}-\kappa \mathrm{B}$ expression in both cell lines in a concentration-dependent manner. As previous study showed $\mathrm{NF}-\kappa \mathrm{B}$ have been linked to regulation of VEGF production (57), we conclude nobiletin antagonizes VEGF expression through NF- $\kappa$ B (Fig. 7).

The proposed mechanism by which nobiletin hampers angiogenesis involves lowering concentrations of VEGF regulators, namely HIF-1 $\alpha$ and NF- $\kappa$ B (Fig. 7). We found nobiletin to have little effect on c-Myc, PTEN, and p-mTOR expression, which indicates that nobiletin does not inhibit expression of VEGF through PTEN/mTOR pathways, neither is c-Myc the key protein that is affected by nobiletin treatment in ovarian cells. Noteworthy, both HIF-1 $\alpha$ and Akt were demonstrated to play direct roles in VEGF secretion. Overexpression of either protein in the presence of nobiletin neutralized its VEGF diminishing effects. Since Akt phosphorylation is intimately linked to HIF-1 $\alpha$ activation, it is likely nobiletin exerts its cancer fighting properties through blocking Akt phosphorylation. Impeding Akt activity likewise reduces HIF-1 $\alpha$ and $\mathrm{NF}-\kappa \mathrm{B}$ levels, subsequently dropping VEGF production and obstructing angiogenesis. Considering all the evidence, we believe this is the central pathway through which nobiletin mediates its tumor limiting effects.

Importantly, our in vitro research conducted agrees with both of our in vivo models. In our CAM model, nobiletin treatment significantly reduced not only the tumor size but also the number of blood vessels, confirming its potency in countering angiogenesis. Furthermore, nobiletin also suppressed tumor growth rates of CP-70 human ovarian cancer cells in the nude mouse model. The administration of nobiletin did not cause any discomfort in mice. The weights of mice, their food intake, water intake were unaffected by the administration of nobiletin (data not shown).

The challenge of conventional chemotherapy in ovarian cancer is that chemotherapeutic drugs are also toxic to normal ovarian epithelial cells. We find that nobiletin potently inhibits the viability of human ovarian cancer cells, and has minimal effects of the viability of normal ovarian cells. The selective inhibitory effect might be at least partly attributed to the apoptosis and anti-angiogenesis induced by nobiletin. Overexpression and activation of Akt, which results in the survival of cancer cells that normally undergo apoptosis (58), occurs in different kinds of cancers, such as gastric, lung, panacreatic and ovarian cancer (59). Nobiletin inhibits overian cancer cells selectively, possibly due to its effect on the phosphorylation of Akt.

Platinum drugs have been most frequently applied for the treatment of cancers including ovarian cancer. However, acquired resistance to conventional platinum based chemotherapy has become a major impediment in cancer treatment. Novel therapies that can reverse drug resistance or kill drug resistant ovarian cancer cells directly are highly desired. Flavonoid compounds like tangeretin (60) and kaempferol 
(61) have been shown to sensitize ovarian cancer cells to the apoptotic effects of cisplatin. Since nobiletin selectively inhibits ovarian cancer cells, it is expected that nobiletin may be useful both as a single agent as well as in combination therapies in the treatment of ovarian cancers.

\section{Acknowledgements}

This study was supported by a grant of the West Virginia Experimental Program to Stimulate Competitive Research and NIH grants (5P20RR016477 and 8P20GM103434) from the National Institutes of Health awarded to the West Virginia IDeA Network of Biomedical Research Excellence.

\section{References}

1. Jemal A, Tiwari RC, Murray T, Ghafoor A, Samuels A, Ward E, Feuer EJ and Thun MJ; American Cancer Society: Cancer statistics, 2004. CA Cancer J Clin 54: 8-29, 2004.

2. Jemal A, Siegel R, Xu J and Ward E: Cancer statistics, 2010. CA Cancer J Clin 60: 277-300, 2010.

3. Bast RC Jr, Xu FJ, Yu YH, Barnhill S, Zhang Z and Mills GB: CA 125: The past and the future. Int J Biol Markers 13: 179-187, 1998.

4. Winstead ER: Ovarian cancer study raises questions about developing markers for early detection. NCI cancer bulletin [On-line serial], 8 (5). Available ncicancerbulletin@mail.nih.gov Message: NCI Cancer Bulletin, March 8, 2011.

5. Fishman DA and Schwartz PE: Current approaches to diagnosis and treatment of ovarian germ cell malignancies. Curr Opin Obstet Gynecol 6: 98-104, 1994.

6. Greenlee RT, Hill-Harmon MB, Murray T and Thun M: Cancer statistics, 2001. CA Cancer J Clin 51: 15-36, 2001.

7. Bosetti C, Rossi M, McLaughlin JK, Negri E, Talamini R, Lagiou P, Montella M, Ramazzotti V, Franceschi S and LaVecchia C: Flavonoids and the risk of renal cell carcinoma. Cancer Epidemiol Biomarkers Prev 16: 98-101, 2007.

8. Bosetti C, Bravi F, Talamini R, Parpinel M, Gnagnarella P, Negri E, Montella M, Lagiou P, Franceschi S and La Vecchia C: Flavonoids and prostate cancer risk: A study in Italy. Nutr Cancer 56: 123-127, 2006.

9. Theodoratou E, Kyle J, Cetnarskyj R, Farrington SM, Tenesa A, Barnetson R, Porteous M, Dunlop M and Campbell H: Dietary flavonoids and the risk of colorectal cancer. Cancer Epidemiol Biomarkers Prev 16: 684-693, 2007.

10. Adhami VM, Malik A, Zaman N, Sarfaraz S, Siddiqui IA Syed DN, Afaq F, Pasha FS, Saleem M and Mukhtar H: Combined inhibitory effects of green tea polyphenols and selective cyclooxygenase- 2 inhibitors on the growth of human prostate cancer cells both in vitro and in vivo. Clin Cancer Res 13: 1611-1619, 2007.

11. Choi EJ, Kim T and Lee MS: Pro-apoptotic effect and cytotoxicity of genistein and genistin in human ovarian cancer SK-OV-3 cells. Life Sci 80: 1403-1408, 2007.

12. Seo HS, DeNardo DG, Jacquot Y, Laïos I, Vidal DS, Zambrana CR, Leclercq G and Brown PH: Stimulatory effect of genistein and apigenin on the growth of breast cancer cells correlates with their ability to activate ER alpha. Breast Cancer Res Treat 99: 121-134, 2006.

13. Fang J, Zhou Q, Liu LZ, Xia C, Hu X, Shi X and Jiang BH: Apigenin inhibits tumor angiogenesis through decreasing HIF-1alpha and VEGF expression. Carcinogenesis 28: 858-864, 2007.

14. Birt DF, Hendrich S and Wang W: Dietary agents in cancer prevention: Flavonoids and isoflavonoids. Pharmacol Ther 90: 157-177, 2001.

15. Gossner G, Choi M, Tan L, Fogoros S, Griffith KA, Kuenker M and Liu JR: Genistein-induced apoptosis and autophagocytosis in ovarian cancer cells. Gynecol Oncol 105: 23-30, 2007.

16. Spinella F, Rosanò L, Di Castro V, Decandia S, Albini A, Nicotra MR, Natali PG and Bagnato A: Green tea polyphenol epigallocatechin-3-gallate inhibits the endothelin axis and downstream signaling pathways in ovarian carcinoma. Mol Cancer Ther 5: 1483-1492, 2006
17. Brusselmans K, Vrolix R, Verhoeven G and Swinnen JV: Induction of cancer cell apoptosis by flavonoids is associated with their ability to inhibit fatty acid synthase activity. J Biol Chem 280: 5636-5645, 2005.

18. Nogata Y, Sakamoto K, Shiratsuchi H, Ishii T, Yano M and Ohta H: Flavonoid composition of fruit tissues of citrus species. Biosci Biotechnol Biochem 70: 178-192, 2006.

19. Murakami A, Nakamura Y, Torikai K, Tanaka T, Koshiba T, Koshimizu K, Kuwahara S, Takahashi Y, Ogawa K, Yano M, et al: Inhibitory effect of citrus nobiletin on phorbol ester-induced skin inflammation, oxidative stress, and tumor promotion in mice. Cancer Res 60: 5059-5066, 2000.

20. Kohno H, Yoshitani S, Tsukio Y, Murakami A, Koshimizu K, Yano M, Tokuda H, Nishino H, Ohigashi H and Tanaka T: Dietary administration of citrus nobiletin inhibits azoxymethane-induced colonic aberrant crypt foci in rats. Life Sci 69: 901-913, 2001.

21. Suzuki R, Kohno H, Murakami A, Koshimizu K, Ohigashi H, Yano M, Tokuda H, Nishino $\mathrm{H}$ and Tanaka T: Citrus nobiletin inhibits azoxymethane-induced large bowel carcinogenesis in rats. Biofactors 22: 111-114, 2004.

22. Lam KH, Alex D, Lam IK, Tsui SK, Yang ZF and Lee SM: Nobiletin, a polymethoxylated flavonoid from citrus, shows antiangiogenic activity in a zebrafish in vivo model and HUVEC in vitro model. J Cell Biochem 112: 3313-3321, 2011

23. Kunimasa K, Ikekita M, Sato M, Ohta T, Yamori Y, Ikeda M, Kuranuki S and Oikawa T: Nobiletin, a citrus polymethoxyflavonoid, suppresses multiple angiogenesis-related endothelial cell functions and angiogenesis in vivo. Cancer Sci 101: 2462-2469, 2010.

24. Kunimasa K, Kuranuki S, Matsuura N, Iwasaki N, Ikeda M, Ito A, Sashida Y, Mimaki Y, Yano M, Sato M, et al: Identification of nobiletin, a polymethoxyflavonoid, as an enhancer of adiponectin secretion. Bioorg Med Chem Lett 19: 2062-2064, 2009.

25. Saito T, Abe D and Sekiya K: Nobiletin enhances differentiation and lipolysis of 3T3-L1 adipocytes. Biochem Biophys Res Commun 357: 371-376, 2007.

26. Miyata Y, Sato T, Yano M and Ito A: Activation of protein kinase $\mathrm{C} \beta \mathrm{II} / \varepsilon$-c-Jun NH2-terminal kinase pathway and inhibition of mitogen-activated protein/extracellular signal-regulated kinase $1 / 2$ phosphorylation in antitumor invasive activity induced by the polymethoxy flavonoid, nobiletin. Mol Cancer Ther 3: 839-847, 2004.

27. Miyata Y, Sato T, Imada K, Dobashi A, Yano M and Ito A: A citrus polymethoxyflavonoid, nobiletin, is a novel MEK inhibitor that exhibits antitumor metastasis in human fibrosarcoma HT-1080 cells. Biochem Biophys Res Commun 366: 168-173, 2008.

28. Luo H, Li B, Li Z, Cutler SJ, Rankin GO and Chen YC: Chaetoglobosin $\mathrm{K}$ inhibits tumor angiogenesis through downregulation of vascular epithelial growth factor-binding hypoxia-inducible factor $1 \alpha$. Anticancer Drugs 24: 715-724, 2013.

29. Fang J, Cao Z, Chen YC, Reed E and Jiang BH: 9- $\beta$-D-Arabinofuranosyl-2-fluoroadenine inhibits expression of vascular endothelial growth factor through hypoxia-inducible factor-1 in human ovarian cancer cells. Mol Pharmacol 66: 178-186, 2004.

30. Blancher C, Moore JW, Robertson N and Harris AL: Effects of ras and von Hippel-Lindau (VHL) gene mutations on hypoxiainducible factor (HIF)-1 $\alpha$, HIF-2 $\alpha$, and vascular endothelial growth factor expression and their regulation by the phosphatidylinositol 3'-kinase/Akt signaling pathway. Cancer Res 61: 7349-7355, 2001.

31. Laughner E, Taghavi P, Chiles K, Mahon PC and Semenza GL: HER2 (neu) signaling increases the rate of hypoxia-inducible factor $1 \alpha(\mathrm{HIF}-1 \alpha)$ synthesis: Novel mechanism for HIF-1mediated vascular endothelial growth factor expression. Mol Cell Biol 21: 3995-4004, 2001

32. Stiehl DP, Jelkmann W, Wenger RH and Hellwig-Bürgel T: Normoxic induction of the hypoxia-inducible factor 1alpha by insulin and interleukin-1beta involves the phosphatidylinositol 3-kinase pathway. FEBS Lett 512: 157-162, 2002.

33. Miura T, Chiba M, Kasai K, Nozaka H, Nakamura T, Shoji T, Kanda T, Ohtake Y and Sato T: Apple procyanidins induce tumor cell apoptosis through mitochondrial pathway activation of caspase-3. Carcinogenesis 29: 585-593, 2008.

34. Jeong WS and Kong ANT: Biological properties of monomeric and polymeric catechins: Green tea catechins and procyanidins. Pharm Biol 42 (s1): 84-93, 2004. 
35. Luo $\mathrm{H}$, Rankin GO, Juliano $\mathrm{N}$, Jiang $\mathrm{BH}$ and Chen $\mathrm{YC}$ : Kaempferol inhibits VEGF expression and in vitro angiogenesis through a novel ERK-NFкB-c-Myc-p21 pathway. Food Chem 130: 321-328, 2012.

36. Chu EC and Tarnawski AS: PTEN regulatory functions in tumor suppression and cell biology. Med Sci Monit 10: RA235-RA241, 2004.

37. Hay N and Sonenberg N: Upstream and downstream of mTOR. Genes Dev 18: 1926-1945, 2004.

38. Ferrara N: Vascular endothelial growth factor as a target for anticancer therapy. Oncologist 9 (Suppl 1): 2-10, 2004.

39. Ramakrishnan S, Subramanian IV, Yokoyama Y and Geller M: Angiogenesis in normal and neoplastic ovaries. Angiogenesis 8: 169-182, 2005.

40. Hazelton D, Nicosia RF and Nicosia SV: Vascular endothelial growth factor levels in ovarian cyst fluid correlate with malignancy. Clin Cancer Res 5: 823-829, 1999.

41. Alvarez AA, Krigman HR, Whitaker RS, Dodge RK and Rodriguez GC: The prognostic significance of angiogenesis in epithelial ovarian carcinoma. Clin Cancer Res 5: 587-591, 1999.

42. Duyndam MC, Hilhorst MC, Schlüper HM, Verheul HM, van Diest PJ, Kraal G, Pinedo HM and Boven E: Vascular endothelial growth factor-165 overexpression stimulates angiogenesis and induces cyst formation and macrophage infiltration in human ovarian cancer xenografts. Am J Pathol 160: 537-548, 2002.

43. Hefler LA, Mustea A, Könsgen D, Concin N, Tanner B, Strick R, Heinze G, Grimm C, Schuster E, Tempfer C, et al: Vascular endothelial growth factor gene polymorphisms are associated with prognosis in ovarian cancer. Clin Cancer Res 13: 898-901, 2007.

44. Forsythe JA, Jiang BH, Iyer NV, Agani F, Leung SW, Koos RD and Semenza GL: Activation of vascular endothelial growth factor gene transcription by hypoxia-inducible factor 1 . Mol Cell Biol 16: 4604-4613, 1996.

45. Lam IK, Alex D, Wang YH, Liu P, Liu AL, Du GH and Lee SM: In vitro and in vivo structure and activity relationship analysis of polymethoxylated flavonoids: Identifying sinensetin as a novel antiangiogenesis agent. Mol Nutr Food Res 56: 945-956, 2012.

46. Luo H, Rankin GO, Liu L, Daddysman MK, Jiang BH and Chen YC: Kaempferol inhibits angiogenesis and VEGF expression through both HIF dependent and independent pathways in human ovarian cancer cells. Nutr Cancer 61: 554-563, 2009.

47. Jiang BH and Liu LZ: AKT signaling in regulating angiogenesis. Curr Cancer Drug Targets 8: 19-26, 2008.

48. Hu L, Hofmann J and Jaffe RB: Phosphatidylinositol 3-kinase mediates angiogenesis and vascular permeability associated with ovarian carcinoma. Clin Cancer Res 11: 8208-8212, 2005.
49. Shi MD, Liao YC, Shih YW and Tsai LY: Nobiletin attenuates metastasis via both ERK and PI3K/Akt pathways in HGF-treated liver cancer HepG2 cells. Phytomedicine 20: 743-752, 2013.

50. Lee YC, Cheng TH, Lee JS, Chen JH, Liao YC, Fong Y, Wu CH and Shih YW: Nobiletin, a citrus flavonoid, suppresses invasion and migration involving FAK/PI3K/Akt and small GTPase signals in human gastric adenocarcinoma AGS cells. Mol Cell Biochem 347: 103-115, 2011.

51. Kar S, Palit S, Ball WB and Das PK: Carnosic acid modulates $\mathrm{Akt} / \mathrm{IKK} / \mathrm{NF}-\mathrm{KB}$ signaling by PP $2 \mathrm{~A}$ and induces intrinsic and extrinsic pathway mediated apoptosis in human prostate carcinoma PC-3 cells. Apoptosis 17: 735-747, 2012.

52. Kim MO, Moon DO, Heo MS, Lee JD, Jung JH, Kim SK, Choi YH and Kim GY: Pectenotoxin-2 abolishes constitutively activated NF- $\kappa \mathrm{B}$, leading to suppression of NF- $\kappa \mathrm{B}$ related gene products and potentiation of apoptosis. Cancer Lett 271: 25-33, 2008.

53. Ozes ON, Mayo LD, Gustin JA, Pfeffer SR, Pfeffer LM and Donner DB: NF- $\kappa$ B activation by tumour necrosis factor requires the Akt serine-threonine kinase. Nature 401: 82-85, 1999.

54. van Uden P, Kenneth NS and Rocha S: Regulation of hypoxiainducible factor- $1 \alpha$ by NF-kappaB. Biochem J 412: 477-484, 2008.

55. Karin M: Nuclear factor-kappaB in cancer development and progression. Nature 441: 431-436, 2006

56. Lin YG, Kunnumakkara AB, Nair A, Merritt WM, Han LY, Armaiz-Pena GN, Kamat AA, Spannuth WA, Gershenson DM, Lutgendorf SK, et al: Curcumin inhibits tumor growth and angiogenesis in ovarian carcinoma by targeting the nuclear factor-kappaB pathway. Clin Cancer Res 13: 3423-3430, 2007.

57. Gonzalez-Perez RR, Xu Y, Guo S, Watters A, Zhou W and Leibovich SJ: Leptin upregulates VEGF in breast cancer via canonic and non-canonical signalling pathways and NFkappaB/ HIF-1alpha activation. Cell Signal 22: 1350-1362, 2010.

58. Testa JR and Bellacosa A: AKT plays a central role in tumorigenesis. Proc Natl Acad Sci USA 98: 10983-10985, 2001.

59. Cain K, Langlais C, Sun XM, Brown DG and Cohen GM: Physiological concentrations of $\mathrm{K}^{+}$inhibit cytochrome $c$-dependent formation of the apoptosome. J Biol Chem 276: 41985-41990, 2001.

60. Arafa SA, Zhu Q, Barakat BM, Wani G, Zhao Q, El-Mahdy MA and Wani AA: Tangeretin sensitizes cisplatin-resistant human ovarian cancer cells through downregulation of phosphoinositide 3-kinase/Akt signaling pathway. Cancer Res 69: 8910-8917, 2009.

61. Luo H, Daddysman MK, Rankin GO, Jiang BH and Chen YC: Kaempferol enhances cisplatin's effect on ovarian cancer cells through promoting apoptosis caused by down regulation of c-Myc. Cancer Cell Int 10: 16, 2010. 